\title{
The Relevance of Public Governance to National Environmental Performance
}

\author{
Andre Basrija \\ Ernst and Young Indonesia \\ Sofik Handoyo \\ Faculty of Economics and Business \\ Universitas Padjadjaran
}

\begin{abstract}
The study aims to examine the influence of public governance on national environmental performance. Public governance in this study consists of four attributes, namely government accountability, political stability, government effectiveness, and regulatory quality. This study was triggered by the phenomenon that countries with excellent economic performance, but they do not always have an excellent national environmental performance. The study involved 155 countries member of World Bank countries. This study adopted a Purposive Sampling technique. Path analysis was applied in this study because there is a correlation among independent variables. Public governance was measured using the Worldwide Governance Indicator (WGI) scores by the World Bank. Meanwhile, environmental performance was measured using the Environmental Performance Index (EPI) score by The Yale Center for Environmental Law \& Policy (YCELP). Simultaneously, the result indicates that government accountability, political stability, government effectiveness, and regulatory quality have a significant influence on national environmental performance. However, partially, only government effectiveness has a significant influence on national environmental performance. Meanwhile, government accountability, political stability, and regulatory quality do not have a substantial effect on national environmental performance.
\end{abstract}

Keywords: Environmental performance; Government accountability; Political stability; Government effectiveness; Regulatory quality

\section{Introduction}

Activities carried out by humans give a considerable influence on the environment (Cochran, 2017). There is plenty of evidence that human activity can influence the environment. One of the environmental issues related to the impact of human activities is global warming. Global warming, in general, is caused by industrialization and deforestation. Global warming occurs because of the accumulation of $\mathrm{CO} 2$ in the atmosphere earth that comes from combustion activity such as cars, planes, and coal plants caused by humans and activities deforestation and thermal stratification. The existence of a causal relationship between human activity with its environment began to raise awareness of the world community to preserve and preserve the environment. United Nations Conference on the Environment on July 15, 1972, in Stockholm, Sweden is the earliest evidence of human attention to the environment. The latest is the Sustainable Development Goals (SDGs) initiated by the United Nations (UN). It implies that environmental issues 
are significant for the international community and at the same time, become a challenge to deal with it collectively (Scruggs, 1999). The Yale Center for Environmental Law \& Policy (YCELP) developed index widely know as the Environmental Performance Index (EPI). It was developed for measuring national environment performance using ten dimensions of issues related environment namely; health impact, air, water and quality sanitation, water resources, agriculture, forestry, fisheries, biodiversity and habitat, and climate and energy.

$$
\text { National environmental }
$$

performance is a reflection of practice of industrialization and environment policy and management (Handoyo, 2015). Generally, the nations with friendly environmental, they also have high economic prosperity. However, increasing industrialization tends to obstruct the quality of the environment (Roy \& Goll, 2014). Alvarez (2014) argued that national environmental performance increases along with the rise of national revenues level. Economy growth reflected by national revenues per capita and environmental performance has a positive and significant relationship (Alvarez, 2014). Jahn (1998) argued that the nation with high Gross Domestic Product (GDP) has adequate financial resources to overcome the problems related to environmental issues.

However, if analyzed further, it was found that national environmental performance did not depend on GDP per capita. Based on EPI data in 2016, it was found that the country with the highest EPI score does not mean having the highest GDP. Finland has the highest EPI score, however its GDP per capita only $\$ 43,090.25$, which is lower than the GDP of Icelandic that has an EPI score in second place. French has an EPI score at position 10 (ten). However, the GDP of French is $\$ 36,854.97$, which is exceeding GDP per capita countries like Slovenia, Spain, Portugal, Estonia, and Malta, which has the EPI score above France. It began to arise the thought that other factors affect the environmental performance of the nation other than economic conditions. Esty and Porter (2005) explained that there are significant differences in national environmental performance, even though they are on the same economic level. Based on the authors perspective, national environmental performance is not only a function of economic performance but also other aspects, such as public governance.

National environmental performance is influenced by two parties, which play an essential role, namely government as a regulator and private companies as industry players (Handoyo, 2015). According to the World Bank, regulation is one of the indicators used in assessing public governance of the nation. National environmental performance can be affected by the practice of public governance (Dasgupta 2006). There are six attributes of public governance, namely government accountability, political stability, government effectiveness, regulation quality, the rule of law as well as control of corruption. In this study, authors are focusing only on four attributes of six attributes. It refers to public governance attributes, namely government accountability, stability politics, government effectiveness, and quality regulation. The purpose of the study is to reveal the influence of public governance attributes on national environmental performance.

\section{Literature Review and Hypothesis Development}

\section{Stakeholders theory}

The concept of stakeholders theory developed by Freeman explains about corporate behavior and social performance (Ghomi and Leung, 2013). Stakeholders theory describe that the company has responsibilities to the parties that both directly or indirectly related to the company (Freeman, 1984). Based on stakeholder 
theory, the company is the entity that operates not only for its own interests but also must give benefits to the related stakeholders. The existence of a company is influenced by the support of the stakeholders (Ghozali and Chariri, 2007). Therefore, companies should also contribute to the stakeholders. One of the most important stakeholders of a business organization is the government. Concerning the government, the business organization will follow the rules and regulations from the government, including the matter related environmental quality protection from the harmful effects of business operation.

\section{Environmental performance}

Environmental performance is a measure related protection of the environment, which includes water, air, land, ecosystems, and natural resources (Bran et al., 2011; Grafton and Knowles, 2003). According to Scruggs (1999), environmental performance is a result of human response to environmental pollution problems. In measuring national environmental performance, there is no specific standard indicator commonly used (Fiorino, 2010). According to Fiorino (2010), Environmental Performance Index (EPI) is an indicator that the most representative measurement in describing the national environmental performance. EPI provides a focus of attention on two purposes, namely (1) reduction of the ecological burden that has an impact on humans health and (2) protection of ecosystems and natural resources (Alvarez et al., 2014). The EPI final score is converted to a scale of 0 (very bad) up to 100 (very good).

\section{Public Governance}

The World Bank defines public governance as a way of implementation power in regulating the country. Governance is believed as the key to achieving the goals that have been set by the government. In the context of government, most researchers, policymakers, aid agencies, and recipients assistance recognize that good governance is a fundamental recipe for achieving sustainable development (Kaufmann and Kraay, 2007). In helping measure public governance, the World Bank has issued a standard measure adopting credit rating mechanism used by world financial institutions. That measure is known as The Worldwide Governance Indicators (WGI). There are six attributes of public governance identified by the World Bank, namely (1) Accountability, (2) Political stability, (3) Effectiveness of government, (4) Quality of regulation, (5) Regulations and legislation, and (6) Corruption control. Each of these indicators has a score that ranges between -2.5 (weak) to $+2,5$ (strong).

\section{Government Accountability and National Environmental Performance}

Accountability is defined by the OECD (2005) as an obligation to present reports of the responsibility implementation through political structures and constitutional. Rationalization between accountability with environmental performance is that funds are collected from the community used by the government to provide facilities for the benefit of the wider community including health support to improve the quality of life of the community. The government is required to disclose in conveying performance has been achieved, including issues related to the environment (Rechtschaffen and Markell, 2003). According to Bianchini and Ravely (2011), accountability has a relationship with environmental performance in terms of fiscal factors. The budget collected by the government from the community in the form of tax must accountable back to society. Therefore, the hypothesis is formulated as follows: 
Hypothesis 1: National environmental performance is affected by government accountability, the higher government accountability index, the higher national environmental performance will be

\section{Political Stability and National Environmental Performance}

Political stability is associated with a conducive condition of government covering internal, regional, and international. Rationalization between political stability and national environmental performance equals thinking of the relationship between political stability and economic growth. Investors have interest and trust to invest their capital in a country with a stable political condition.

When a country has a stable political situation, then the country will not be preoccupied with political issues so the country can focus more on economic development, including environment issues (Handoyo, 2015) Kelleher et al. (2009) argued that the national environmental performance is dependent on the institution politics. It implies that if the political condition of a country is stable, then policies taken by the government are more focus on national development, including policies relating to environmental protection. Therefore, the hypothesis is formulated as follows:

Hypothesis 2: National environmental performance is affected by national political stability, the higher national political stability, the higher national environmental performance will be.

\section{Government Effectiveness and National Environmental Performance}

Government effectiveness refers to the capabilities of internal government institutions to achieve the objectives stated in national development planning
(Handoyo, 2015). If the government institution functions well, then the problems related to the environment will be solved. Effective government institutions will be more successful in fighting environmental degradation compared to weak government institutions (Duit, 2005). Therefore, the hypothesis is formulated as follows:

Hypothesis 3: National environmental performance is affected by government effectiveness, the higher government effectiveness, the higher national environmental performance will be

\section{Regulations Quality and National Environmental Performance}

According to Coglinanese (2012), regulations is the rules and norms that are adopted by the government accompanied by the consequences in the form of sanctions for whom who break it. Regulation quality can be measured by identifying the ability of regulations in achieving the goals previously determined. The quality of regulation will determine the environmental performance of the country (Esty and Porter, 2001).

High-quality regulation will help realize public policy objectives which include safety, security, health, and environment (Treasury Board of Canada Secretariat, 2011). Strict regulations will provide incentives for governments and business organization to be more flexible to work together in achieving better environmental performance (Scruggs, 1999). Therefore, the hypothesis is formulated as follows:

Hypothesis 4: National environmental performance is affected by regulation quality, the higher quality of regulation, the higher national environmental performance will be 


\section{Research Methodology}

This study treated public governance as an independent variable and national environmental performance as the dependent variable. Public governance in this study includes four attributes, namely government accountability, political stability, government effectiveness, and regulatory quality. This research involved 155 countries member of the World Bank selected using purposive sampling technique. The type of data used in this study is quantitative secondary data sourced from the Environmental Performance Index (EPI) report and the Worldwide Governance Indicators (WGI) report for the period 2010, 2014 and 2016. The data was obtained through the official website of YCELP and World Bank. The 2012 report data cannot be used because of differences in reporting data with the 2012 EPI report which made it incomparable with other reporting years. The analytical method used in this study is path analysis because there is an indication of a strong relationship among variables independent. Through path analysis, the direct effect of four attributes of public governance on national environmental performance, as well as its indirect effect can be identified.
The equation of the research model formulated as follows:

$\mathrm{Y}=\rho \mathrm{yX} 1+\rho \mathrm{XX} 2+\rho \mathrm{XX} 3+\rho \mathrm{X} 4+\mathrm{e}$, Where;

$\mathrm{Y}=$ Dependent variable

$\mathrm{X}_{1}, \mathrm{X}_{2}=$ Independent variable

$\mathrm{P}=$ =Path coefficient between independent and dependent variables

e $\quad=$ residual variables

\section{Results}

This study applied a program named statistical data processing application Eviews version 10. The reason for using Eviews statistical application because of data was tested in this study is a type of panel data. The model test was conducted before doing the regression analysis and path analysis. The Chow test was conducted to identify the fitness research model. The Chow test is used to determine whether the selected model is pooled least square or fixed effect. $\mathrm{H} 0$ is rejected if the value of probability $\mathrm{F}$ is smaller than Alpha, which is smaller than 0.05 . $\mathrm{H} 0$ is a pooled least square model and $\mathrm{H} 1$ is a fixed effect model. The result of the Chow Test presented in Table 1

Tabel 1. Chow Test Result

\begin{tabular}{|l|l|l|}
\hline Chow-Test & Statistic & Prob. \\
\hline Cross-section F & 1.517035 & 0.0011 \\
\hline
\end{tabular}

Based on the information presented in Table 1 above, it can be identified that the probability of cross-section $\mathrm{F}$ is 0.0011 which means less than the value of $\alpha$ $(0.0011<0.05)$ so that the decision taken is using the fixed effect model. Because the Chow test decision is to choose the fixed effect model, then a Hausman test is needed to decide whether the panel data used in this study is better estimated by using a random effect model or still using the fixed effect model. Based on the results of the Hausman test that have been carried out obtained the following results presented in Table 2 .

Tabel 2. Hausman Test Result

\begin{tabular}{|c|c|c|}
\hline Hausman Test & Statistic & Prob. \\
\hline Cross-section Chi-square $\left(\mathrm{X}^{2}\right)$ & 1.334439 & 0.8555 \\
\hline
\end{tabular}


Based on the information presented in Table 2 above, it can be identified that the value of chi-square $\left(\mathrm{X}^{2}\right)$ probability is 0.8555 , which means that it is greater than
$0.05(0.8555>0.05)$ so that the decision taken is using a random effect model. Descriptive analysis was conducted to describe the data of each variable studied.

Table 3. Descriptive Analysis

\begin{tabular}{lccccc}
\hline & $\begin{array}{c}\text { National } \\
\text { Environmental } \\
\text { Performance }\end{array}$ & $\begin{array}{c}\text { Government } \\
\text { accountability }\end{array}$ & $\begin{array}{c}\text { Political } \\
\text { stability }\end{array}$ & $\begin{array}{c}\text { Government } \\
\text { Effectiveness }\end{array}$ & $\begin{array}{c}\text { Regulation } \\
\text { Quality }\end{array}$ \\
\hline Observations & 465 & 465 & 465 & 465 & 465 \\
Mean & 58.23959 & -0.10 & -0.10 & 0.01 & 0.02 \\
Maximum & 93.50 & 1.68 & 1.53 & 2.24 & 2.23 \\
Minimum & 18.43 & -2.26 & -2.48 & -2.06 & -2.27 \\
Std. Dev. & 14.84077 & 0.97873 & 0.85634 & 0.96678 & 0.98102 \\
\hline
\end{tabular}

Based on the descriptive analysis summarized in Table 3, it can be identified that the average value of environmental performance is 58.23959. Whereas for public governance attributes have an average value between -0.10 to 0.02 . This figure illustrates that the sample, in general, has poor government accountability $\left(\mathrm{X}_{1}\right)$ and political stability $\left(\mathrm{X}_{2}\right)$ below moderate value, but has good government effectiveness $\left(\mathrm{X}_{3}\right)$ and regulatory quality $\left(\mathrm{X}_{4}\right)$ (above moderate values). All variables appear to have high category standard deviations, so it can be assumed that the sample has a variety of environmental performance and high governance.

The highest environment performance value reaches 93.50 , which is owned by the Icelandic National (2010), while the lowest value is 18.43 owned by Mali (2014). The highest value of government accountability reaches 1.68 , which is owned by the Norway (2014), while the lowest value is -2.26 owned by the Turkmenistan (2014). The highest value of political stability reaches 1.53 owned by the Singapore (2016), while the lowest value is -2.48 owned by the Iraq (2014). The highest government effectiveness value reaches 2.24, which is owned by Singapore (2010), while the lowest value is
-2.06 owned by Haiti (2016). The highest quality regulation value reaches 2.23 owned by the Singapore (2014), while the lowest value is -2.27 which is owned by the Libya (2016).

Gujarati and Porter (2009) explained that the equations that meet the classical assumptions are equations using the Generalized Least Square (GLS) method. In the Eviews data processing program, the estimation model that uses the Generalized Least Square (GLS) method is only a random effect model, while the common effect model and fixed effect model use the Ordinary Least Square (OLS) method. Because the results of the model test in the panel data regression using random-effect models, in this study, there is no need to test classical assumptions. Correlation analysis was conducted to identify the strength of the relationship between variables idependents and variables dependen. The level of strength of relationships between variable dependent (environmental performance) and variable independent (Government accountability, government effectiveness, political stability, regulation quality) can be identified through the value of the correlation coefficient. The summary of correlation analysis is shown in Table 4. 
Table 4. Correlation Analysis

\begin{tabular}{lccccc}
\hline \multicolumn{1}{c}{ Variable } & $\begin{array}{c}\text { Environmental } \\
\text { Performance }\end{array}$ & $\begin{array}{c}\text { Government } \\
\text { accountability }\end{array}$ & $\begin{array}{c}\text { Political } \\
\text { stability }\end{array}$ & $\begin{array}{c}\text { Government } \\
\text { Effectiveness }\end{array}$ & $\begin{array}{c}\text { Regulation } \\
\text { Quality }\end{array}$ \\
\hline $\begin{array}{l}\text { Environmental } \\
\text { Performance }\end{array}$ & 1 & & & & \\
$\begin{array}{l}\text { Government } \\
\text { accountability }\end{array}$ & 0.431 & 1 & & & \\
$\begin{array}{l}\text { Political stability } \\
\text { Government }\end{array}$ & 0.399 & 0.597 & 1 & & \\
$\begin{array}{l}\text { Effectiveness } \\
\text { Regulation Quality }\end{array}$ & 0.559 & 0.734 & 0.710 & 1 & \\
\hline
\end{tabular}

Based on information in Table 4 above, it can be identified that government accountability $\left(\mathrm{X}_{1}\right), \quad$ government effectiveness $\left(\mathrm{X}_{3}\right)$, and regulatory quality $\left(\mathrm{X}_{4}\right)$ have correlations a reasonably strong with the country's environmental performance (correlation value is between $0.40-0.599)$, while political stability $\left(\mathrm{X}_{2}\right)$ has low correlation (correlation value between 0.20 - 0.399). Thus, overall the attributes of public governance have a strong positive correlation with the national environmental performance. It means that an increase in the value of public governance will be followed by an increase in the value of the national environmental performance.
In addition, Table 4 shows that government accountability $\left(\mathrm{X}_{1}\right)$ and political stability $\left(\mathrm{X}_{2}\right)$ has a strong correlation (correlation value between 0.60 - 0.799) to government effectiveness $\left(X_{3}\right)$, while regulatory quality $\left(\mathrm{X}_{4}\right)$ has a very strong correlation (correlation value between 0.80 - 1.00). It means that the value of government effectiveness is very dependent on the value of government accountability, political stability, and the quality of regulation. After conducting correlation analysis, path analysis is next procedure to identity the influence of each independent variables on variable dependent both individually or simultaneously. The results of path analysis are presented in Table 5.

Table 5. Path Analysis

\begin{tabular}{|l|c|c|c|}
\hline \multicolumn{1}{|c|}{ Variable } & Path Coeficient & $\begin{array}{c}\text { Simultaneously } \\
\text { Effect }\end{array}$ & Residual Effect \\
\cline { 1 - 2 } Government Accountability & 0,100 & & \\
\cline { 1 - 2 } Political Stability & $-0,006$ & 0,31965 & 0,68035 \\
\cline { 1 - 2 } Government Effectiveness & 0,701 & & \\
\cline { 1 - 2 } Regulation Quality & $-0,228$ & & \\
\hline
\end{tabular}

Based on resluts of Path analysis presented in Table 5, the path equation is formulated as $\mathrm{Y}=0,100 \mathrm{X}_{1}-0,006 \mathrm{X}_{2}+$ $0,701 X_{3}-0,228 X_{4}$. The effect of government accountability on the national environmental performance $\left(\mathrm{Pyx}_{1}\right)$ is 0.100 with a positive sign. The path coefficient for the influence of political stability on the national environmental performance $\left(\mathrm{Pyx}_{2}\right)$ is 0.006 with a negative sign. Path coefficient for the effect of government effectiveness on the national environmental performance $\left(\mathrm{Pyx}_{3}\right)$ is 0.701 with a positive sign. The path coefficient for the influence of regulatory quality on the national environmental performance $\left(\mathrm{Pyx}_{4}\right)$ is 0.228 with a negative sign. The path coefficient value of the government effectiveness variable $\left(\mathrm{X}_{3}\right)$ is the highest among the other variables, which is equal to 0.701 . This 
shows that the government effectiveness variable is very decisive value of the national environmental performance compared to the variables of government accountability, political stability, and quality of regulation both directly and indirectly.

Based on Table 5, it can also be identified that the influence of the four attributes of governance on a national environmental performance is 0.31965 or around $31.965 \%$, while the influence of other factors outside of this study on the national environmental performance is at 0.68035 or around $68.035 \%$. In other words, national environmental performance can be explained by $31.965 \%$ by the government accountability, political stability, and quality of regulation. Meanwhil, the remaining $68.035 \%$ can be explained by other variables not examined in this study. Therefore, in the future, adding others variables related national environmental performance is relevance. Characteristic of the nation such as population density, poverty index, national income, education index, economic growth, purchasing power are relevant factors to be investigated.

The following is a path diagram that illustrates the influence of government accountability $\left(\mathrm{X}_{1}\right)$, political stability $\left(\mathrm{X}_{2}\right)$, government effectiveness $\left(\mathrm{X}_{3}\right)$, and quality of regulation $\left(\mathrm{X}_{4}\right)$ on national environmental performance $(\mathrm{Y})$.

Diagram 1. Path Diagram

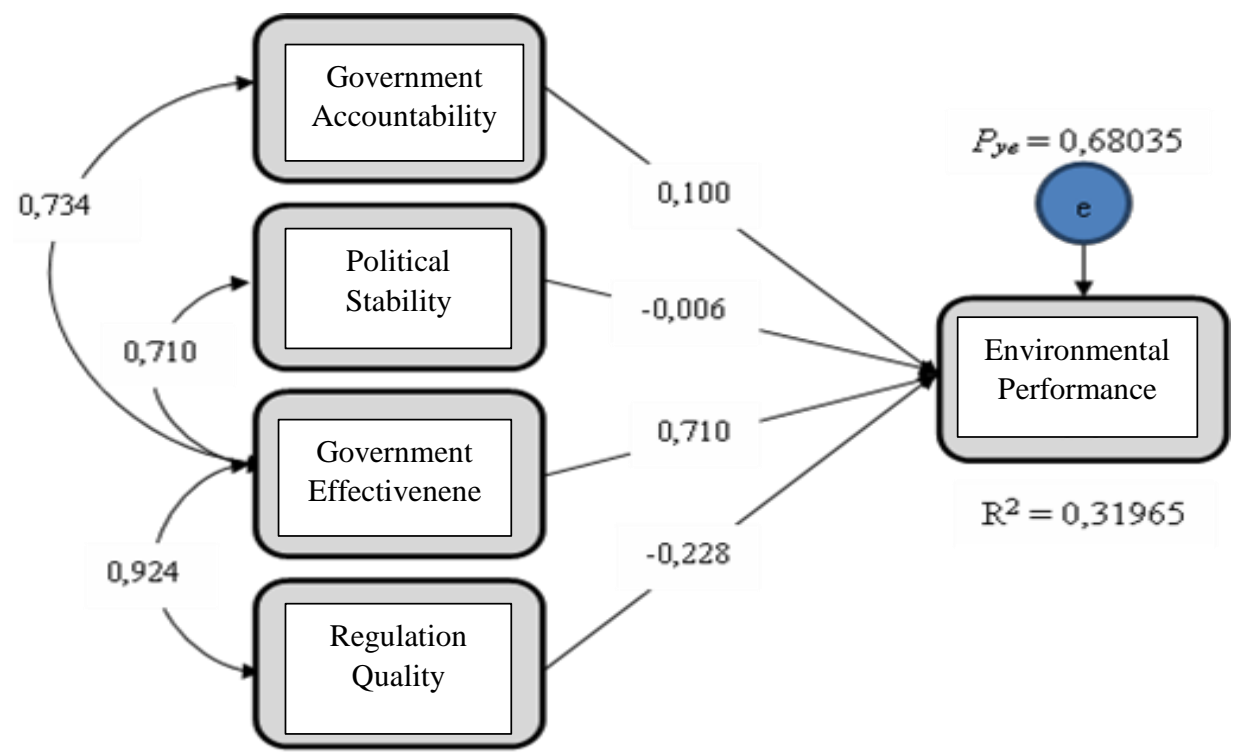

Based on the results of data processing using Eviews 10, the results of statistical test to make conclusion related the hypothesis proposed are presented in Table 6.

Table 6. F Test and t-Test

\begin{tabular}{lcccc}
\hline & $\begin{array}{c}\text { Environmental } \\
\text { Performance }\end{array}$ & $\begin{array}{c}\text { Government } \\
\text { accountability }\end{array}$ & $\begin{array}{c}\text { Political } \\
\text { stability }\end{array}$ & $\begin{array}{c}\text { Government } \\
\text { Effectiveness }\end{array}$ \\
\hline Uji F (F Prob.) & 0.0000 & 0.0000 & 0.0000 & 0.0000 \\
Uji t (t-Prob.) & 0.1570 & 0.8380 & 0.0000 & 0.0631 \\
\hline
\end{tabular}


Based on Table 6 above, it can be identified that the F-statistical probability value is smaller than the value of $\alpha$ ( $p$ $<0.05$ ). Using a confidence level of $95 \%$, the decision related the hypothesis 1 is to reject. It means that government accountability, political stability, government effectiveness, and quality of regulation simultaneously have a

significant influence on national environmental performance.

Based on information presented in Table 6, partial analysis indicated that only government effectiveness has a significant influence on the national environmental performance. It was showed with the value of t-statistical probability that is smaller than the value of $\alpha(p<0.05)$. Government accountability (prob. T-stat $=0.1570$ ), political stability (prob. T-stat $=0.8380)$, and the quality of regulation (prob. T-stat $=$ 0.0631) does not have a significant effect on national environmental performance ( $t-$ statistical probability value is greater than $\alpha)$.

\section{Conclusion}

Government $\begin{array}{r}\text { accountability, } \\ \text { golitical stability, avernment }\end{array}$
effectiveness, and quality of regulation
simultaneously have a significant influence
on national environmental performance. Government accountability does not have a significant influence on national environmental performance. It means that good or bad government accountability in certain country does not have an impact on its national environmental performance. Political stability does not have a significant influence on the environmental performance. It means that whetere the country has stability or not the political conditions, it will not have an impact on its national environmental performance. The effectiveness of government has a significant and positive influence on the national environmental performance. It means that the higher government effectiveness, the higher national environmental performance will be. The quality of regulation does not have a significant effect on the national environmental performance, which means that the better the quality of regulation of a country does not affect the national environmental performance.

\section{Refferences}

Aidt, T. S. (2009). Corruption, Institutions and Economic Development. Oxford Review of Economic Policy 25 , 271291.

Alhaddi, H. (2015). Triple Bottom Line and Sustainability: A Literature Review. Business and Management Studies, Vol 1, No.2.

Alvarez, I. G., Galindo, M. P., Villardon, M. P., \& Rosa, M. R. (2014). Environmental Performance in Countries Worldwide: Determinant Factors and Multivariate Analysis.

Anaya, S., \& William Jr., R. (2001). The Protection of Indigenous Peoples' Rights Over Lands and Natural Resources Under The InterAmerican Human Rights System. 14 Harvard Human Rights Journal 33.

Applied Corporate

Governance. http://www.appliedcorporate- governance.com/definebusiness-ethics.html

Avram, Botha Christina. (2014).

Good Governance and Doing Business: Evidence From A CrossCountry Survey. Transylvanian Review of Administrative Science.

Arikunto. (2010). Prosedur Penelitian: Suatu Pendekatan Praktek. Jakarta: Rineka Cipta. 
Bianchini, Laura and Reveli, Federico. (2011). Green Polities: Urban Environmental Performance and Government Popularity. The IEB Working Paper.

Borghei-Ghomi, Zahra and Leung, Philomena. (2013). An Empirical Analysis of the Determinants of Greenhouse Gas Voluntary Disclosure in Australia. Sciedu Press Vol 2, No 1, 110-127.

Bosse, D. A., Phillips, R. A., \& Harrison, J. S. (2009). Stakeholders, Reciprocity and Firm Performance. Strategic Management Journal, 30: 447-56.

Bran, Lorina., Radulescu, Carmen Valentina., Ioan, Ildiko. (2011). Measures of Environmental Performance. Review of International Comparative Management.

Breaban \& Sandu. (2013) Using Environmental Performance Index to Assess Regional Resilience in Romania. Conference Paper.

Breslin, Conor. (2017). Role of Government in Business Ethics. Accessed at http://smallbusiness.chron.com/rolegovernment-business-ethics65128.html

Cochran, A Lynn. (2017). Effect of Human Activities on The Environment. Accessed at https://sciencing.com/effect-humanactivities- environment-11374.html

Coglinanese, Cary. (2012). Measuring Regulatory Performance: Evaluating The Impact of Regulation and Regulatory Policy. OECD Expert Paper No. 1

Conca, K. \& Wallace, J. (2009). Environment and Peacebuilding in
War-Torn Societies: Lessons from The UN Environment Programmes's Experience with Postconflict Assessment. Global Governance 15, 485-504.

Csanyi, Carolyn. (2017).

Examples of Deforestation. Accessed at https://sciencing.com/examplesdeforestation- 12319812.html

Damania, R., Fredriksson, P. G., and List, J.A. (2003). Trade Liberalization, Corruption, and Environmental Policy Formulation: Theory and Evidence. Journal of Environmental Economics and Management 46(3), 490-512

Dasgupta, Susmita., Hamilton, Kirk., Pandey, Kiran D., Wheeler, David. (2006). Environmental During Growth: Accounting for Governance and Vulnerability. World Bank.

Duit, A. (2005). Understanding Environmental Performance of Nationals: An Institution Centered Approach and Some Difficulties. Working Paper Serie. 7. Göteborg University: Göteborg, Sweden.

E. Ferlie, L. Lynne \& C. Pollitt. (2004), The Oxford Handbook of Public Management. Oxford: Oxford University Press.

Ekici, Ahmet and Onsel, Sule. (2013). How Ethical Behavior of Firms is Influenced by the Legal and Political Environments: A Bayesian Causal Map Analysis Based on Stages of Development. Journal of Business Ethics Vol. 115, No. 2.

Esty, Daniel C. dan Porter, Michael. (2005). National Environmental Performance: An Empirical Analysis 
of Policy Results and Determinants. Environ. Dev. Econ, 10, 391-434.

Fiorino, Daniel J. (2010). Explaining National Environmental Performance: What Do We Know and What Should We Learn?. Center for Environmental Policy Department of Public Administration and Policy Working Paper.

Fredriksson, Per G. \& Svensson, Jakob. (2003). Political Instability, Corruption and Policy Formation: The Case of Environmental Policy. Journal of Public Economics.

Freeman, R. Edward,. (2008). Environment, Ethics, and Business. Business Roundtable Institute for Corporate Ethics.

Freeman, R. Edward. (1984). Strategic Management: A Stakeholder Approach. Boston: Pitman.

Ghozali, Imam. (2013). Aplikasi Analisis Multivariate dengan Program SPSS. Edisi Ketujuh. Semarang: Badan Penerbit Universitas Diponegoro.

Ghozali, Imam \& Chariri, Anis. (2007). Teori Akuntansi Universitas Diponegoro. Semarang: Badan Penerbit Universitas Diponegoro.

Grafton, R. Quentin \& Knowles, Stephen. (2003). Social Capital and National Environmental Performance. Australian National University Economics and Environment Network Working Paper EEN 0206.

Gujarati dan Porter. 2009. Dasar-Dasar Ekonometrika. Jakarta: Salemba Empat.

Gujarati, Damodar N. (2006). Essentials of Econometrics. Third Edition. McGraw-Hill International Edition.
Handoyo, Sofik., Fitriyah, F. K., Suciati, Handiani. (2015). The Relationship of Public Governance and Environmental Sustainability Performance.

Handoyo, Sofik,. (2018). The Development of Indonesia Environmental Performance and Environmental Compliance. Journal of Accounting Auditing and Business, Vol.1, No.1

Hill, Charles W.L. \& Jones, Gareth R. (2010). Strategic Management Theory An Integrated Approach. South-Western: Cengage Learning.

Himpunan Pemerhati
Lingkungan Hidup Indonesia.
Isu Lingkungan. Accessed
at http://www.hpli.org/isu.php

Hsu, A. et al. (2016). 2016 Environmental Performance Index. New Haven, CT: Yale University. Available: www.epi.yale.edu.

Jahn, D. (1998). Environmental Performance and Policy Regimes: Explaining Variations in 18 OECDCountries. Pol. Sci 31, 107-131.

Katsamunska, Polya. (2016). The Concept of Governance and Public Governance Theories. Economic Alternatives, Issue 2.

Kaufman and Kraay. (2007). Governance Indicators: Where Are We, Where Should We Be Going?. Policy Research Working Paper 4370. World Bank.

Kaufmann, Daniel., Kraay, Aart., \& Mastruzzi, Massimo. (2010). The Worldwide Governance Indicators: Methodology and Analytical Issues. Global Economy and Development at Brookings. 
Kelleher, David., Kim, Geum-Soo., Chang, Young-Jae. Do Differences in Political Institutions Explain Differences in Environmental Policy Performance Across Countries?. Paper Presented at The APPAM- KDI International Conference on Environmental Policy and Teaching Methods (Seoul, June 11-13, 2009).

Kjar, A.M. (2004). Governance. United Kingdom: Polity Press.

Kuncoro, M. (2011). Metode Kuantitatif. Yogyakarta: Unit Penerbit dan Percetakan AMP YKPN.

Law, D and Versteeg, M. (2012), The Declining Influence of the United Nationals Constitution, 87 New York University Law Review 762, 773-5. Lopez, R., \& S. Mitra. (2000). Corruption, Pollution, and The Kuznets Environment Curve. Journal of Environmental Economics and Management 40(2), 137-150.

Lubchenco, J. (1998). Entering The Country of the Environment: A New Social Contract for Science. Science 279, 491-492.

Magraw, Daniel Barstow. (2015). Rule of Law, Environment and Sustainable Development. Southwestern Journal of International Law. Vol.21.

OECD. (2010). Regulatory Policy and The Road to Sustainable Growth. OECD Report.

OECD. (2008). Measuring Regulatory Quality. OECD Observer.

OECD. (2005). Modernizing Government: The Way Forward. Paris: OECD.

Ozanian, Andrew. (2015). Why Rule of Law is The Bedrock of Sustainable
Development.

Accessed athttps://www.weforum.org/agenda/ 2015/09/w hy-rule-of-law-is-thebedrock-of-sustainabledevelopment/

Paddock, Leroy. (2004). Environmental Accountability and Public Involvement. Pace Environmental Law Review. Col. 21, issue 2.

Phillips, R. A. (2003). Stakeholder Theory and Organizational Ethics. San Francisco: Berrett- Koehler Publishers.

Pierre, J. \& Peters, B. Guy. (2000). Governance, Politics and the National. Macmillan: Press Ltd.

Priyanto, Dwi. (2009). Mandiri Belajar SPSS. Jakarta: PT. Buku Kita, hal. 40.

Rahman, Lutfor. (2016). Governance and Good Governance: A Theoretical Framework. Public Policy and Administration Research. Vol. 6, No. 10.

Rechtschaffen, Clifford., \& Markell, David. (2003). Improving National Environmental Enforcement Performance Through Enhanced

Government Accountability and Other Strategies. Golden Gate University School of Law, Publications.

Riduwan. (2010). Skala Pengukuran Variabel- Variabel Penelitian. Bandung: Alfabeta.

Riduwan dan Engkos. (2012). Cara Mudah Menggunakan dan Memakai Path Analysis (Analisis Jalur). Bandung: Alfabeta.

Roy, A., \& Goll, I. (2014). Predictors of Various Facets of Sustainability of 
Nations: The Role of Cultural and Economic Factors. International Business Review, 23(5), 849-861. Scruggs, Lyle A. (1999). Institutions and Environmental Performance in Seventeen Western Democracies. British Journal of Political Science, Volume 29, Issue 01.

Smith, B.C. (2007). Good Governance and Development. Palgrave Macmillan.

Sugiyono. (2013). Metode Penelitian Bisnis. Jakarta : CV. Alvabeta.

Sullivan, John D. (2009). The Moral Compass of Companies: Business Ethics and Corporate Governance as Anti-Corruption Tools. International Finance Corporation. 2121 Pennsylvania Avenue, NW Washington.

Sundström, Aksel. (2013). Corruption in The Commons: Why Bribery Hampers Enforcement of Environmental Regulations in South African Fisheries. International Journal of the Commons Vol. 7, no 2.

Tasyir, Eyup Aygun., Pazarcik, Yener. (2013). Business Ethics, Social
Responsibility, and Corporate Governance: Does The Strategic Management Field Really Care About These Concepts?. ProcediaSocial and Behavioral Science.

Treasury Board of Canada Secretariat. (2011). Indicators of Regulation and Regulatory Policy Performance Canada's Vision Madrid Workshop.

Venkataramanan, M \& Smitha. (2011). Causes and Effects of Global Warming. Indian Journal of Science and Technology Vol. 4 Issue 3.

Wälti, S. How multilevel structures affect environmental policy in industrialized countries. Eur. J. Pol. Res. 2004, 43, 599-634.

Wang, Hua. \& Di, Wenhua. (2002). The Determinants of Government Environmental Performance: An Empirical Analysis of Chinese Townships. World Bank Policy Research Working Paper2937.

Welsch, H. (2004). Corruption, Growth, and The Environment: A CrossCountry Analysis. Environment and Development Economics 9, 663-693 